\title{
PENGEMBANGAN LEMBAR KERJA SISWA BERBASIS PROBLEM BASED LEARNING MATERI BANGUN RUANG SISI LENGKUNG
}

\author{
Moh. Robet Syaekhoni ${ }^{1}$, Eric Dwi Putra' ${ }^{2}$, Dwi Noviani Sulisawati ${ }^{3}$ \\ 1,2 3 Pendidikan Matematika, IKIP PGRI Jember \\ robert.math96@gmail.com¹, dwieric454@gmail.com², \\ dwi.moshimoshi@gmail.com ${ }^{3}$
}

\begin{abstract}
Abstrak
Penelitian ini bertujuan untuk menghasilkan LKS berbasis model problem based learning pada materi bangun ruang sisi lengkung ditinjau dari aspek kevalidan, kepraktisan, dan keefektifan. Penelitian ini merupakan penelitian pengembangan dengan model pengembangan 4D yang terdiri dari pendifinisian (define), perancangan (design), pengembangan (develop), dan penyebaran (disseminate). Instrumen yang digunakan yaitu (1) lembar validasi, (2) observasi keterlaksanaan LKS dalam pembelajaran, (3) aktivitas siswa dan guru, (4) angket respon siswa dan tes hasil belajar. Subjek penelitian ini adalah siswa kelas IX A di SMP As-Syafi'i Rambipuji. Kualitas LKS dilihat dari aspek kevalidan termasuk dalam kategori valid dengan rata-rata skor penilaian ahli materi sebesar 4,18 dan rata-rata skor penilaian oleh ahli media sebesar 4,24 dengan kategori valid. Dilihat dari aspek kepraktisan LKS dinyatakan praktis dengan observasi keterlaksanaan LKS dalam pembelajaran mendapatkan skor rata-rata sebesar 4,41 dengan kategori tinggi. Dari aspek keefektifan LKS dinyatakan efektif berdasarkan hasil observasi aktivitas siswa mendapatkan skor sebesar 88,1\% dengan kategori sangat baik. Hasil observasi aktivitas guru mendapatkan skor sebesar 92,5\% dengan kategori baik. Hasil analisis tes hasil belajar dari 25 siswa yang menjadi subjek penilitian 21 (84\%) siswa tuntas dan 4 (6\%) siswa tidak tuntas. Hasil penilaian angket respon siswa mendapatkan skor rata-rata sebesar 4,07 dengan kategori baik. Dengan demikian LKS yang dikembangkan dinyatakan efektif.
\end{abstract}

Kata kunci: Penelitian Pengembangan, LKS, PBL

\begin{abstract}
This study aims to produce student worksheets based on a problembased learning model for curved side space building materials in terms of validity, practicality, and effectiveness. This research is a development research with a 4D development model which consists of define, design, develop, and disseminate. The instruments used were (1) validation sheets, (2) observations of the implementation of worksheets in learning, (3) student and teacher activities, (4) student response questionnaires and learning outcomes tests. The subjects of this study were students of class IX A at SMP As-Syafi'i Rambipuji. The quality of the worksheets seen from the validity aspect is included in
\end{abstract}


the valid category with an average score of 4.18 and the average score of assessment by media experts is 4.24 with the valid category. Judging from the practicality aspect, the student worksheet is stated to be practical by observing the implementation of the student worksheet in learning to get an average score of 4.41 in the high category. From the aspect of effectiveness, the student worksheet was declared effective based on the results of observations of student activities getting a score of $88.1 \%$ in the very good category. The results of the observation of teacher activity get a score of $92.5 \%$ in a good category. The results of the analysis of the learning outcomes test of 25 students who were the subjects of the study $21(84 \%)$ students completed and $4(6 \%)$ students did not complete. The results of the student response questionnaire assessment got an average score of 4.07 with a good category. Thus the worksheets developed are declared effective.

Keywords: Development Research, Student Worksheets, Problem

Based Learning

\section{PENDAHULUAN}

Kegiatan belajar dan mengajar di sekolah merupakan suatu sistem yang tidak bisa lepas dari beberapa komponen yang saling berinteraksi di dalamnya. Salah satu komponen dalam proses tersebut adalah sumber belajar. Menurut Musfiqoh, HM (2012) "Sumber belajar adalah kebutuhan pokok yang penting untuk menjadi sumber informasi, sumber peraga, sumber alat, serta kebutuhan lain yang diperlukan selama proses pembelajaran". Selain itu menurut Amalia, R dan Putra, DE (2017) "Sumber belajar ialah semua hal yang memiliki pesan, baik yang dikembangkan dengan sengaja atau dapat dimanfaatkan untuk memberikan pengalaman belajar dan atau kegiatan praktik yang memungkinkan terjadinya belajar. Sumber belajar bisa dari berbagai macam bentuk seperti buku, nara sumber, teknik, media non-buku, dan lingkungan". Media merupakan bagian dari proses berkomunikasi yang menunjang proses belajar mengajar di kelas. Menurut AECT (Susilana, R dan Riana, C, 2007) bahwa: "Media adalah segala bentuk dan saluran yang digunakan untuk proses penyaluran pesan". Menurut Hidayah dan Sugiarto (Hamdani, 2011) menyebutkan: Lembar Kerja Siswa (LKS) ialah salah satu jenis alat bantu pembelajaran". Secara umum LKS dapat berupa lembar kertas yang berisikan informasi dan/ atau soal-soal yang akan digunakan sebagai pelengkap atau pendukung bagi pelaksanaan pembelajaran. Lembar Kerja Siswa sebaiknya dirancang sesuai dengan pokok bahasan dan tujuan pembelajaran. Selain itu Lembar Kerja Siswa sebaiknya beriskan informasi tentang materi yang terstruktur dan ringkas, serta tugas yang diberikan yang berguna untuk mengevaluasi pemahaman materi. Akan tetapi Lembar Kerja Siswa yang banyak tersedia saat ini bersifat praktis, 
instan, pengemasan yang demikian membuat siswa hanya dapat menghafal tanpa bisa memahami materi sehingga ketika siswa memperoleh soal yang bervariasi mereka kesulitan untuk mengerjakan dan membuat mereka bingung.

Tanggal 16 Mei 2020 peneliti melaksanakan wawancara singkat dengan guru Matematika di SMP As-Syafi'i Rambipuji. Dari hasil wawancara tersebut didapatkan kesimpulan sebagian besar siswa tidak begitu antusias dalam mengikuti pembelajaran matematika dan siswa menganggap matematika itu sulit. Fakta di lapangan ini sejatinya memberikan gambaran sebagaimana yang dikatakan oleh Tyas (2016) yang menyatakan bahwa pada saat ini sebagian besar siswa yang mengalami kesulitan dalam mempelajari, memahami dan mengaplikasikan materi matematika. Hal ini terjadi juga karena pembelajaran di sana monoton menggunakan metode ceramah dan tanya jawab sehingga sering membuat siswa bosan.

Banyak faktor yang bisa menyebabkan pada siswa kesulitan dalam mempelajari matematika. Faktor yang mempengaruhi kesulitan belajar siswa bisa terdiri dari faktor internal dan eksternal. Dalam hal ini, faktor ekternal bisa mencakup tentang belum bervariasinya metode mengajar yang diterapkan oleh guru sehingga siswa tidak dapat terlibat aktif secara fisik dalam pembelajaran, serta sarana dan prasarana yang masih belum memadai (Fajriyani, 2020). Sehingga peneliti ingin memberikan masukan berupa LKS yang akan dikembangkan ini sebagai salah satu sumber belajar yang digunakan siswa. Selain LKS siswa juga menggunakan buku paket untuk sumber belajar. Menurut beliau perlu diadakan pengembangan LKS yang dapat memfasilitasi kebutuhan siswa sehingga ketika siswa menggunakan LKS tersebut dapat menjadi inovasi dan variasi baru dalam upaya peningkatan kualitas pembelajaran matematika di SMP serta mampu meningkatkan hasil belajar dan aktivitas siswa.

Salah satu LKS yang dipandang peneliti bisa memfasilitasi kebutuhan siswa tersebut yaitu Lembar Kerja Siswa berbasis model Problem Based Learning. Problem Based Learning (PBL) adalah pembelajaran yang diawali dari suatu permasalahan yang digunakan sebagai sarana untuk investigasi siswa. Permasalahan yang disajikan di awal pembelajaran merupakan masalah yang autentik dan bermakna. Setiap siswa atau kelompok belajar diharuskan untuk dapat menyelesaikan semua permasalahan yang diberikan oleh guru secara mandiri. Dengan siswa berusaha memecahkan masalah yang mereka hadapi secara mandiri, pembelajaran yang sedang berlangsung memiliki tujuan agar siswa mampu mendapatkan pengetahuannya agar lebih bermakna. Hal ini sejalan dengan pendapat yang dikemukanan oleh Bruner (Trianto 2009: 91) yaitu suatu konsekuensi logis, bahwa dengan memecahkan masalah secara mandiri melalui pengalaman-pengalamannya, 
siswa akan menggunakan pengalaman pemecahan masalah tersebut untuk memecahkan masalah yang serupa, hal ini dikarenakan pengalaman memberikan suatu makna tersendiri bagi seorang siswa. Pembelajaran matematika sendiri juga memiliki tujuan agar siswa dapat mengembangkan kemampuannya dalam menyelesaikan setiap permasalahan yang mereka hadapi hingga mampu menambah keimanan dan ketaqwaannya kepada Tuhan Yang Maha Esa, berilmu, kreatif, cakap dan berakhlak mulia (Depdiknas, 2003).

Banyak dari penelitian-penelitian lain yang mencoba untuk membantu siswa dalam mengurangi kesulitan yang dihadapinya ketika menghadapi mata pelajaran matematika, khususnya pada materi bangun ruang sisi lengkung. Seperti penelitian yang telah dilakukan oleh Zaqiyah, dkk (2020) yang telah berhasil mengembangkan modul pembelajaran berbasis Realistic Mathematics Education untuk pembelajaran bangun ruang sisi lengkung. Tetapi penelitian tersebut hanya menghasilkan modul atau buku panduan dan belum merambah ke bagian aktivitas siswa yang berhubungan dengan Lembar Kerja Siswa. Selanjutnya penelitian yang telah dilakukan Sulisawati (2017) melalui penerapan pembelajaran matematika berbasis masalah dengan bantuan buku siswa untuk siswa kelas VIII SMP Darul Hikmah Jember juga mampu menunjukkan adanya peningkatan ketuntasan hasil belajar siswa yang cukup signifikan sehingga model pembelajaran ini dapat dijadikan sebagai salah satu alternatif pembelajaran yang diterapkan kepada siswa.

Lembar Kerja Siswa berbasis model Problem Based Learning ini juga membuat suasana belajar lebih menyenangkan dan bermanfaat serta mengakui usaha dari setiap siswa, memberikan pujian dan penghargaan kepada siswa yang berhasil dengan memanfaatkan lingkungan sekitar (penataan ruang belajar) dan permasalahan yang ada sehingga siswa bisa lebih tertarik untuk mengikuti pelajaran dan benar-benar memahami materi yang dipelajari. Pemahaman masalah selama pelaksnaan proses pemecahan masalah dalam suatu rangkaian pembelajaran dianggap sebagai hal yang paling penting untuk segera diselesaikan terutama untuk kebanyakan pemula yang baru melakukan proses pemecahan masalah (Sulisawati, 2019). Berdasarkan hal tersebut, maka pada artikel ini penting untuk dilakukan suatu penelitian pengembangan PBL dalam pembelajaran matematika yang dituangkan dalam judul "Pengembangan LKS Berbasis Problem Based Learning Untuk Materi Pembelajaran Bangun Ruang Sisi Lengkung Di Kelas IX SMP As-Syafi'i Rambipuji" dengan memperhatikan bagaimana proses dan hasil pengembangan Lembar Kerja Siswa Berbasis Problem Based Learning untuk materi pembelajaran bangun ruang sisi lengkung ditinjau dari aspek kevalidan, kepraktisan, dan juga keefektifan. 


\section{METODE PENELITIAN}

Jenis penelitian pada penelitian ini mengacu kepada Research and Development (R\&D) dengan menggunakan model pengembangan model 4-D. Model pengembangan 4-D (Four D) ialah salah satu model pengembangan untuk mengembangkan perangkat pembelajaran. Model ini dikembangkan oleh S. Thiagarajan, Dorothy S. Semmel, dan Melvyn I. Model pengembangan 4D terdiri atas 4 tahap utama yaitu: Define (Pendefinisian), Design (Perancangan), Develop (Pengembangan) dan Disseminate (Penyebaran) (Thiagarajan, 1974: 5). Lokasi pelaksanaan penelitian ini bertempat di SMP As-Syafi'i Rambipuji. Penelitian ini dilaksanakan di kelas IX A SMP As-Syafi'i Rambipuji dengan jumlah sampel 25 siswa.

Instrumen pengumpulan data pada penelitian menggunakan (1) lembar validasi, (2) lembar observasi keterlaksanaan LKS, (3) lembar observasi aktivitas siswa (4) lembar observasi aktivitas guru, (5) angket respon siswa dan (6) tes hasil belajar.

Validasi seluruh instrumen yang digunakan dalam penelitian divalidasi oleh tiga validator yaitu dua dosen matematika IKIP PGRI Jember dan guru matematika SMP As-Syafi'i Rambipuji. Analisis kevalidan dilakukan sesuai dengan aturan berikut:

a) Merekapitulasi data hasil penilaian tentang kevalidan perangkat kedalam tabel

b) Menghitung nilai rata-rata dari nilai hasil validasi oleh keseluruhan validator untuk tiap indikator

c) Menghitung rerata nilai di tiap aspek

d) Menentukan nilai Va atau rerata total dari rerata nilai untuk semua aspek

e) Selanjutnya nilai Va atau nilai rata-rata total ini dirujuk pada interval penentuan tingkat kevalidan perangkat pembelajaran sebagai berikut.

Tabel 1. Klasifikasi Penilaian Kevalidan

\begin{tabular}{cc}
\hline Interval Skor & Kategori Kevalidan \\
\hline $1 \leq \mathrm{Va}<2$ & Tidak valid \\
$2 \leq \mathrm{Va}_{2}<3$ & Kurang valid \\
$3 \leq \mathrm{Va}<4$ & Cukup valid \\
$4 \leq \mathrm{Va}<5$ & Valid \\
\hline
\end{tabular}

Sumber : Hobri (2010: 53)

Pengukuran kepraktisan LKS dilakukan dengan observasi keterlaksanaan LKS dalam pembelajaran. Observasi dilakukan oleh dua orang observer. Analisis kepraktisan dilakukan dengan langkah-langkah sebagai berikut:

a) Menghitung rekapitulasi hasil observasi keterlaksanaan LKS dalam pembelajaran dan menyajikannya dalam bentuk table. 
b) Menghitung skor rata-rata nilai hasil observasi dari masing-masing pertemuan untuk setiap indicator

c) Menghitung rata-rata nilai untuk tiap aspek pengamatan.

d) Menentukan nilai IO atau nilai rata-rata total dari rata-rata nilai untuk semua aspek

e) Selanjutnya rerata nilai aspek (IO) ini dirujuk pada interval penentuan tingkat keterlaksanaan sebagai berikut.

Tabel 2. Kriteria Penilaian Keterlaksanaan LKS

\begin{tabular}{cc}
\hline Interval Persentase & Kriteria \\
\hline $1 \leq \mathrm{IO}<2$ & Sangat Rendah \\
$2 \leq \mathrm{IO}<3$ & Rendah \\
$3 \leq \mathrm{IO}<4$ & Sedang \\
$4 \leq \mathrm{IO}<5$ & Tinggi \\
$\mathrm{IO}=5$ & Sangat Tinggi \\
\hline
\end{tabular}

Sumber: Hobri (2010: 56)

Pengukuran keefektifan LKS dilakukan dengan observasi aktivitas siswa, observasi aktivitas guru, angket respon siswa dan tes hasil belajar. Untuk observasi aktivitas siswa dan guru dilakukan oleh dua observer yang dilakukan selama pembelajaran berlangsung selama dua kali pertemuan. Tes hasil belajar dilakukan di akhir pembelajaran pada pertemuan ke tiga. Untuk penilaian angket respon siswa dilakukan setelah tes hasil belajar. Analisis data observasi aktivitas siswa dilakukan dengan langkah-langkah sebagai berikut:

a) Tabulasi data, data hasil penilaian pengamatan aktivitas siswa ditabulasi untuk memudahkan langkah selanjutnya.

b) Penghitungan skor rata-rata dengan rumus Ps $=\frac{\mathrm{A}}{\mathrm{N}} \times 100 \%$

c) Mengklasifikasikan skor rata-rata yang diperoleh berdasarkan klasifikasi interpretasi skor keefektifan berikut.

Tabel 3. Klasifikasi Persentase Aktivitas Siswa

\begin{tabular}{cc}
\hline Kategori & Klasifikasi \\
\hline $0 \%-20 \%$ & Sangat Buruk \\
$21 \%-40 \%$ & Buruk \\
$41 \%-60 \%$ & Cukup \\
$61 \%-80 \%$ & Baik \\
$81 \%-100 \%$ & Sangat Baik \\
\hline
\end{tabular}

Sumber : Riduwan (2015:15)

Analisis data observasi aktivitas guru dilakukan dengan langkahlangkah sebagai berikut: 
a) Penghitungan skor rata-rata dengan rumus $P_{g}=\frac{A}{N} \times 100 \%$

b) Mengklasifikasikan skor rata-rata yang diperoleh berdasarkan klasifikasi interpretasi skor keefektifan berikut.

Tabel 4. Klasifikasi Persentase Aktivitas Guru

\begin{tabular}{cc}
\hline Kategori & Persentase \\
Aktifitas & \\
\hline Sangat Baik & $\mathrm{P}_{\mathrm{g}}>95 \%$ \\
Baik & $80 \%<\mathrm{P}_{\mathrm{g}} \leq 95 \%$ \\
Cukup Baik & $65 \%<\mathrm{P}_{\mathrm{g}} \leq 80 \%$ \\
Kurang Baik & $50 \%<\mathrm{P}_{\mathrm{g}} \leq 65 \%$ \\
Tidak Baik & $\mathrm{P}_{\mathrm{g}} \leq 50 \%$ \\
\hline
\end{tabular}

Sumber : Sukardi 1983:100 (dalam Setiawan 2012)

Analisis data tes hasil belajar dilakukan dengan langkah-langkah sebagai berikut.

Ketuntasan tes hasil belajar secara klasikal dihitung dengan cara:

Ketuntasan $(\mathrm{p})=\frac{\text { jumlah siswa yang tntas }}{\text { iumlah siswa yang mengikuti tes }} \times 100 \%$

Tabel 5. Kriteria Ketuntasan Tes Hasil Belajar

\begin{tabular}{cc}
\hline Rentang Skor & Kriteria \\
\hline $90 \%<\mathrm{X} \leq 100 \%$ & Sangat Baik \\
$80 \%<\mathrm{X} \leq 90 \%$ & Baik \\
$65 \%<\mathrm{X} \leq 80 \%$ & Cukup \\
$55 \%<\mathrm{X} \leq 65 \%$ & Kurang \\
$\mathrm{X} \leq 55 \%$ & Sangat Kurang \\
\hline
\end{tabular}

Sumber : M. Ngalim Purwanto (2004:82)

Analisis data angket respon siswa dilakukan dengan langkah-langkah berikut:

a) Tabulasi data yang diperoleh dari lembar evaluasi LKS untuk angket tanggapan siswa

b) Menghitung rata-rata skor masing-masing aspek yang diamati dengan rumus:

c) $\overline{\mathrm{x}}=\frac{\sum_{\mathrm{i}=1}^{\mathrm{n}} \mathrm{xi}}{\mathrm{n}}$

d) Mengonversi skor rata-rata yang diperoleh berdasarkan klasifikasi penilaian skala 5

Tabel 6. Klasifikasi Keefektifan LKS

\begin{tabular}{cc}
\hline Rerata Skor & Klasifikasi \\
\hline $\bar{x}>4,2$ & Sangat Baik \\
$3,4<\bar{x} \leq 4,2$ & Baik \\
$2,6<\bar{x} \leq 3,4$ & Cukup \\
$1,8<\bar{x} \leq 2,6$ & Kurang \\
$\bar{x} \leq 1,8$ & Sangat Kurang \\
\hline
\end{tabular}

Prismatika: Jurnal Pendidikan dan Riset Matematika Vol. 3 No. 2 (2021) p-ISSN: 2654-6140, e-ISSN: 2656-4181

http://ejurnal.budiutomomalang.ac.id/index.php/prismatika 


\section{HASIL DAN PEMBAHASAN}

Rincian tahapan yang dilakukan oleh peneliti adalah sebagai berikut :

\section{Tahap Pendefinisian}

Tahap awal dari penelitian ini adalah melakukan analisis yang terdiri dari analisis awal dan akhir, menganalisis siswa, menganalisis konsep, menganalisis tugas, dan meninjau spesifikasi tujuan pembelajaran. Hasil dari analisis awal akhir yaitu siswa yang tidak begitu antusias dalam mengikuti pelajaran matematika. Saat pelajaran matematika berlangsung ada siswa tidak memperhatikan gurunya, ada yang sedang ngobrol bersama teman sebangku, ada yang bergurau, hanya sedikit siswa yang fokus dalam pembelajaran. Analisis siswa yang dilakukan peneliti yaitu melakukan observasi terhadap siswa SMP As-Syafi'i Rambipuji kelas IX A untuk mengetahui dan menjabarkan kegiatan dan karakteristik siswa yang sesuai dengan rancangan dan tujuan pengembangan LKS. Karakteristik siswa meliputi pengetahuan kita tentang sejauh mana penguasaan kemampuan akademik dan perkembangan kognitif siswa. Selanjutnya pada analisis konsep peneliti menganalisis konsep-konsep yang diperlukan yang akan diajarkan pada proses pembelajaran. Langkah ini memiliki tujuan untuk mengklasifikasi, merinci, dan menyusun konsepkonsep yang relevan secara sistematis yang akan diajarkan sesuai dengan analisis awal-akhir. Saat melakukan analisis tugas peneliti melakukan pengamatan dan mendalami jenis-jenis tugas yang akan diberikan yang bisa juga berupa kompetensi-kompetensi yang akan dikembangkan dalam proses pembelajaran. Pada spesifikasi tujuan pembelajaran peneliti melakukan perumusan tujuan pembelajaran yang diperoleh disesuaikan dengan kompetensi inti dan kompetensi dasar sesuai dengan KTSP.

\section{Tahap Perancangan}

Pada tahap perancangan bertujuan untuk merancang suatu LKS dan instrumen yang digunakan dalam penelitian yang meliputi penyusunan tes, pemilihan format. Penyusunan tes dilakukan pada akhir penelitian untuk mengukur hasil kemampuan siswa, serta untuk mengetahui apakah proses pembelajaran dengan menggunakan model problem based learning berpengaruh pada hasil belajar. Tes tersebut berupa tes uraian yang dapat mengukur kemampuan siswa. Pada pemilihan format meliputi penyusunan peta kebutuhan LKS, penyusunan desain isi RPP, penyusunan desain isi LKS.

Penyusunan desain isi RPP yang dilakukan yaitu menuliskan identitas mata pelajaran meliputi: satuan pendidikan, kelas, semester, mata pelajaran, alokasi waktu, dan jumlah pertemuan. Selanjutnya Standar kompetensi ditulis berdasarkan standar isi 2006. Standar kompetensi 
yang digunakan dalam penelitian ini adalah "Bangun Ruang Sisi Lengkung”. Setelah itu menuliskan kompetensi dasar yang tulis berdasarkan standar isi 2006. Kompetensi dasar yang digunakan adalah (1) Menggeneralisasi rumus luas permukaan dan volume bangun ruang sisi lengkung (tabung), (2) Menyelesaikan soal tentang masalah kontekstual yang berkaitan dengan luas permukaan dan volume bangun ruang sisi lengkung (tabung). Setelah menuliskan KD yang dilakukan adalah menuliskan indicator, tujuan pembelajaran, dan menentukan materi pembelajaran.

\section{Tahap Pengembangan}

Pada tahap pengembangan dilakukan dengan dua kegiatan yaitu tahap validasi seluruh instrumen oleh para ahli dan uji coba LKS.

Adapun hasil validasi dapat dilihat pada tabel berikut.

Tabel 7. Hasil Validasi Instrumen Penelitian

\begin{tabular}{ccc}
\hline Instrumen Penelitian & Skor & Kriteria \\
LKS ahli media & 4,24 & Valid \\
LKS ahli materi & 4,18 & Valid \\
RPP & 4,31 & Valid \\
Soal Tes Hasil Belajar & 4,36 & Valid \\
Angket Respon Siswa & 4,18 & Valid \\
Observasi Keterlaksanaan LKS & 4,2 & Valid \\
Observasi Aktivitas Siswa & 4,31 & Valid \\
Observasi Aktivitas Guru & 4,28 & Valid \\
\hline
\end{tabular}

Berdasarkan tabel 7 diketahui bahwa semua instrumen penelitian yang divalidasi berada dalam kategori valid. Setelah validasi seluruh instrumen peneliti melakukan uji coba lapangan. Uji coba pada penelitian ini dilakukan pada tanggal 20 Agustus - 22 Agustus 2020 di SMP As-Syafi'i Rambipuji kelas IX A. Uji coba pada penelitian ini mendapatkan data berupa observasi keterlaksanaan LKS dalam pembelajaran untuk mengukur kepraktisan LKS, sedangkan angket respon siswa, observasi aktifitas siswa, observasi aktivitas guru dan tes hasil belajar siswa digunakan untuk mengukur keefektifan LKS.

Berdasarkan observasi keterlaksanaan LKS dalam pembelajaran selama tiga pertemuan mendapatkan skor sebagai berikut.

Tabel 8. Hasil Observasi Keterlaksanaan LKS

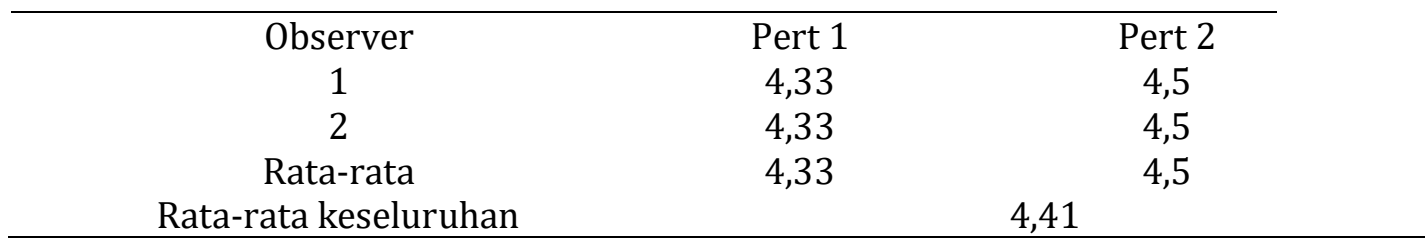


Berdasarkan tabel 8 hasil observasi keterlaksanaan LKS dalam pembelajaran berada dalam kategori tinggi.

Penilaian keefektifan LKS dilakukan dengan menggunakan observasi aktivitas siswa, observasi aktivitas guru, angket respon siswa dan tes hasil belajar siswa.

Hasil dari observasi aktivitas siswa mendapat mendapat presentase keseluruhan sebesar $87 \%$ berada dalam kategori sangat baik. Hasil dari observasi aktivitas guru mendapat presentase keseluruhan sebesar 92,5\% berada dalam kategori baik. Hasil dari angket respon siswa mendapat nilai sebesar 4,07 berada dalam kategori baik. Hasil dari tes hasil belajar siswa didapat sebesar 84\% siswa yang tuntas berada dalam kategori baik. Berdasarkan uraian diatas maka dapat disimpulkan bahwa LKS yang dikembangkan dinyatakan valid, praktis dan efektif.

\section{Tahap Penyebaran}

Pada penelitian ini tahap penyebaran hanya dilakukan penyebaran terbatas yaitu kepada guru matematika lain di SMP As-Syafi'i Rambipuji. Tahap ini merupakan tahap akhir dari proses pengembangan yang dilakukan untuk mempromosikan produk pengembangan agar mampu diterima oleh pengguna secara individu, kelompok ataupun system. Pelaksanaan tahap ini sesuai dengan tahap pelaksanaan penyebaran yang dilakukan oleh Kurniawan (2017) yakni tujuan dari tahap ini adalah untuk melakukan serangkaian tes validasi terhadap perangkat pembelajaran yang telah diujicobakan dan direvisi untuk kemudian disebarkan ke lapangan.

\section{KESIMPULAN DAN SARAN}

Berdasarkan hasil validasi seluruh instrumen yang digunakan dalam penelitian mendapat skor dalam kategori valid, observasi keterlaksanaan LKS dalam pembelajaran mendapat skor dalam kategori tinggi, observasi aktivitas siswa mendapat skor dalam kategori sangat baik, observasi aktivitas guru mendapat skor dalam kategori baik, angket respon siswa mendapat skor dalam kategori baik dan hasil tes belajar mendapat skor dalam kategori baik maka dapat disimpulkan bahwa LKS Berbasis Problem Based Learning Untuk Materi Pembelajaran Bangun Ruang Sisi Lengkung yang dikembangkan dinyatakan valid, praktis dan efektif.

Berdasarkan penelitian yang telah dilakukan maka peneliti memeiliki beberapa saran:

1) Bagi para peneliti selanjutnya diharapkan untuk lebih meningkatkan kualitas produk, sebaiknya produk ini dikembangkan lebih luas lagi untuk materi-materi yang lain dalam pelajaran matematika atau bidang studi lain. 
2) Bagi para peneliti selanjutnya disarankan untuk mengembangkan LKS berbasis model pembelajaran lainnya.

\section{DAFTAR PUSTAKA}

Amalia, R. \& Putra, E.D. (2017). Pengembangan Modul Mata Kuliah Algoritma dan Pemograman (Pemograman C++). Gammath Vol. 02 No. 02 Hal. 02. Disajikan

http://jurnal.unmuhjember.ac.id/index.php/JPM/article/view/641/6 73. Diakses 20 Juni 2018.

Depdiknas. (2013). Undang-Undang Republik Indonesia Nomor 20 Tahun 2003 Tentang Sistem Pendidikan Nasional. Jakarta Departemen Pendidikan Nasional.

Fajriyani, Ety. (2020). Kesulitan Belajar Siswa dalam Mata Pelajaran Matematika Kelas V MIS Islamiyah Margasari 01 Sidareja Cilacap. Skripsi: IAIN Purwokerto. Diakses Melalui http://repository.iainpurwokerto.ac.id/9025/1/Cover_Bab\%20I_Bab \%20V_Daftar\%20Pustaka.pdf pada tanggal 5 Mei 2021.

Hamdani. (2011). Strategi Belajar Mengajar. Bandung : CV Pustaka Setia.

Hobri. (2010). Metodologi Penelitian Pengembangan (Aplikasi Pada Penelitian Pendidikan Matematika). Jember: Pena Salsabila.

Kurniawan, Dian., \& SV. Dewi. (2017). Pengembangan Perangkat Pembelajaran dengan Media Screencasto-matic Mata Kuliah Kalkulus 2 Menggunakan Model 4-D Thiagarajan. Jurnal Siliwangi, Vol. 3, No. 1, 2017 Seri Pendidikan. Diakses melalui https://core.ac.uk/download/pdf/230362617.pdf pada tanggal 4 Mei 2021.

Musfikoh, HM. (2012). Pengembangan Media dan Sumber Pembelajaran. Jakarta : PT. Prestasi Pustakarya.

Riduwan, (2015). Skala Pengukuran Variabel-Variabel Penelitian. Bandung: ALFABETA

Riyana, C., \& Susilana, R. (2007). Media Pembelajaran, Hakikat, Pengembangan, Pemanfaatan dan Penilaian. Bandung: CV. Wacana Prima.

Sulisawati, DN., \& Eric, DP. (2017). Penerapan Pembelajaran Matematika Berbasis Masalah dengan Bantuan Buku Siswa Kelas VIII SMP Darul Hikmah Jember. Seminar Nasional Matematika dan Pendidikan Matematika (2nd Senatik) Program Studi Pendidikan Matematika FPMIPATI - Universitas PGRI Semarang. Diakses melalui http://prosiding.upgris.ac.id/index.php/sen_2017/sen_2017/paper/v iewFile/1670/1652 pada tanggal 6 Mei 2021.

Sulisawati, DN., Lutfiyah., F. Murtinasari ., \& L. Sukma. (2019). Differences of Visual, Auditorial, Kinesthetic Students in Understanding Mathematics Problems. Malikussaleh Journal of Mathematics Learning (MJML), Vol. 2, No. 2, October 2019, pp. 45-51, P-ISSN. 2620-6315, E-ISSN. 26206323. 
Thiagarajan, S., Semmel, D.S. \& Semmel, M.I. (1974). Instruction Development for Training Teachers of Exceptional Children. Indiana: Indiana University Bloomington.

Trianto. (2012). Model Pembelajaran Terpadu Konsep, Strategi dan Implementasinya dalam KTSP. Jakarta: Bumi Aksara.

Tyas, Ni'mah Mulyaning. (2016). Analisis Faktor Penyebab Kesulitan Belajar Matematika Kelas IV di Kecamatan Ungaran Barat Kabupaten Semarang. Skripsi: Universitas Negeri Semarang. Diakses melalui https://lib.unnes.ac.id/24893/1/1401412428.pdf pada tanggal 5 Mei 2021.

Zaqiyah, Kholifatus, dkk. (2020). Pengembangan Modul Berbasis Realistic Mathematics Education untuk Pembelajaran Bangun Ruang Sisi Lengkung. Laplace: Jurnal Pendidikan Matematika, Vol.3, No.2, Oktober 2020. Diakses melalui https://jurnal.ikipjember.ac.id/index.php/Laplace/article/view/381/ 369 pada tanggal 8 April 2021. 